\title{
Сибирь и Индия в евразийском социокультурном пространстве: меридиональное измерение
}

\author{
Андрей В. Иванов, Светлана М. Журавлева \\ Алтайский государственный аграрный университет, Российская Федерация,
} Юрий В. Попков

Институт философии и права СО РАН; Новосибирский государственный технический университет, Российская Федерация

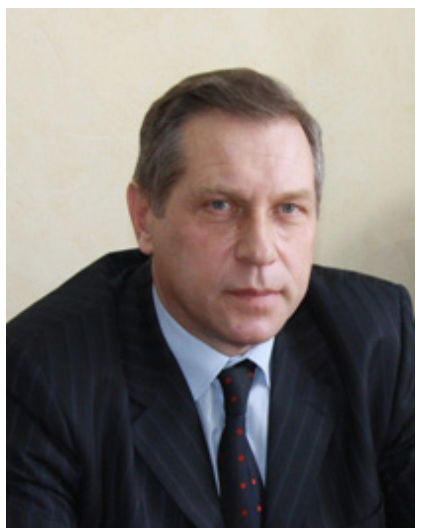

В работе представлен анализ содержания книги известного индийского ученого, специиалиста по Центральной Азии доктора Кулбхушана Варику (K. Warikoo) "Siberia and India: Historical Cultural Affinities” («Сибирь и Индия: историко-культурное родство»). Она была издана на английском языке в Нью-Дели в 2020 г. Международным фондом Вивекананды (Индия). Отмечается, что методологические установки исследования автора близки позициям рецензентов и многих других российских коллег и что данный труд свидетельствует о перспективности сотрудничества индийских и сибирских ученых в самых разных областях, в том числе по линии повышения качества самих исследований и научных публикаций.

Автор пишет, что между Индией и народами Сибири существует явное историкокультурное родство, в частности, благодаря общим традищиям и буддийской культуре. На страницах книги, которая относится к классическому жанру путевых научных очерков, приводятся некоторые наблюдения индийского ученого, сделанные во время путешествий по республикам Бурятия (2007), Хакасия (2009), Алтай (2014 и 2015) и Тыва (2016) Российской Федерации, подтверждающие его тезис. Автор отмечает

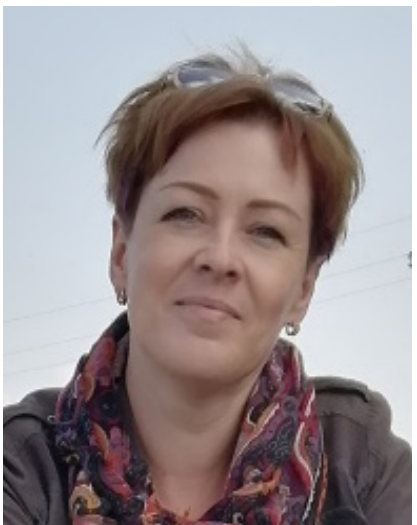
распространенность в традиционной культуре сибирских народов представлений, которые являются характерными и для гималайских народов. Он делает вывод о необходимости дальнейшего выявления общих традиций, верований и обычаев у народов Сибири и Индии, что может стать плодотворной основой научного сотрудничества между сибирскими и индийскими учеными.

Эта идея научного сотрудничества должна способствовать и росту самосознания населения Сибири, занимающей срединное положение на пространствах Евразии и являющейся местом культурного и циивилизационного взаимодействия народов. Обращается внимание на некоторые упущения д-ра Варику, в частности, по проблемам неоднозначности языковой ситуации в Туве.

Ключевые слова: Евразия; Индия; Сибирь; Тува; Алтай; Хакасия; буддизм; буддийский мир; международное сотрудничество; культурно-исторические связи

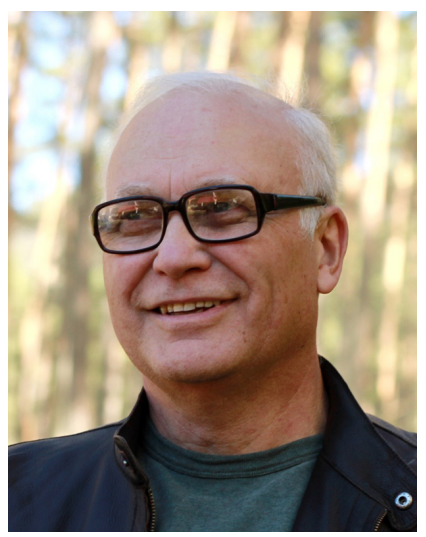

Для цитирования:

Иванов А. В., Журавлева С. М., Попков Ю. В. Сибирь и Индия в евразийском социокультурном пространстве: меридиональное измерение // Новые исследования Тувы. 2021, № 2. С. 169-178. DOI: https://www.doi.org/10.25178/nit.2021.2.14

Иванов Андрей Владимирович - доктор философских наук, профессор, директор Центра гуманитарного образования Алтайского государственного аграрного университета. Адрес: 656049, Россия, г. Барнаул, пр. Красноармейский, д. 98, каб. 419. Тел.: +7 (903) 910-94-62; +7 (3852) 20-33-47. Эл. адрес: ivanov_a_v_58@mail.ru

Журавлева Светлана Михайловна - кандидат философских наук, доцент кафедры гуманитарных дисциплин Алтайского государственного аграрного университета. Адрес: 656049, Россия, г. Барнаул, пр. Красноармейский, д. 98, каб. 421. Тел.: +7 (909) 502-01-65. Эл. адрес: jurav27@yandex.ru

Попков Юрий Владимирович - доктор философских наук, профессор, главный научный сотрудник отдела социальных и правовых исследований Института философии и права Сибирского отделения Российской академии наук; профессор кафедры международных отношений и регионоведения Новосибирского государственного технического университета. Адрес: 630090, Россия, г. Новосибирск, ул. Николаева, д. 8. Тел.: +7 (383) 330-22-40. Эл. адрес: yuripopkov54@mail.ru 


\title{
Siberia and India in the Eurasian Socio-cultural Space: A Meridional Dimension
}

\author{
Andrey V. Ivanov, Svetlana M. Zhuravleva \\ Altai State Agrarian University, Russian Federation, \\ Yuri V. Popkov
}

Institute of Philosophy and Law, Siberian Branch, Russian Academy of Sciences; Novosibirsk State Technical University, Russian Federation

The article presents an analysis of the contents of the book entitled "Siberia and India: Historical Cultural Affinities" by the famous Indian scientist, expert on Central Asia, Dr. Kulbhushan Warikoo. It was published in English in New Delhi in 2020 by the Vivekananda International Foundation (India). It is noted that the methodological guidelines of the author's research are similar to the viewpoints of the reviewers and many other Russian colleagues. This work indicates the prospects for cooperation between Indian and Siberian scientists in various fields, including improving the quality of research and academic publications.

The author writes that there is a clear historical and cultural proximity between India and the peoples of Siberia, in particular, due to common traditions and Buddhist culture. Written in the classical genre of scientific itineraries, the book contains some observations of the Indian scientist made during his travels in the republics of Buryatia (2007), Khakassia (2009), Altai (2014 and 2015) and Tyva (2016) in the Russian Federation. These findings confirm his thesis. The author notes the occurrence of ideas that are characteristic of the Himalayan peoples in the traditional culture of the Siberian ethnic groups. He draws a conclusion that it is necessary to further identify common traditions, beliefs and customs among the peoples of Siberia and India. This can become a fertile basis for scientific cooperation between Siberian and Indian researchers.

This idea of scientific cooperation should also contribute to the growth of self-consciousness of the population of Siberia that occupies the middle position in the Eurasian space and is a place of cultural and civilizational interaction of peoples. Attention is drawn to some omissions of Dr. Warikoo, in particular, regarding the issues of ambiguity of the language situation in Tuva.

Keywords: Eurasia; India; Siberia; Tuva; Altai; Khakassia; Buddhism; Buddhist world; international cooperation; cultural and historical relations

IVANOV, Andrey Vladimirovich, Doctor of Philosophy, Professor, Director, Center for Humanities Education, Altai State Agrarian University. Postal address: 98 Krasnoarmeysky Ave., 656049 Barnaul, Russian Federation. Tel.: +7 (903) 910-94-62; +7 (3852) 20-3347. E-mail: ivanov_a_v_58@mail.ru

ZHURAVLEVA, Svetlana Mikhailovna, Candidate of Philosophy, Associate Professor, Department of Humanities, Altai State Agrarian University. Postal address: 98 Krasnoarmeysky Ave., 656049 Barnaul, Russian Federation. Tel.: +7 (909) 502-01-65; +7 (3852) 20-3347.E-mail: jurav27@yandex.ru

ORCID ID: 0000-0002-8370-7604

POPKOV, Yuri Vladimirovich, Doctor of Philosophy, Professor; Chief Researcher, Department of Social and Legal Studies, Institute of Philosophy and Law, Siberian Branch, Russian Academy of Sciences; Professor, Department of International Relations and Regional Studies, Novosibirsk State Technical University. Postal address: 8 Nikolaev St., 630090 Novosibirsk, Russian Federation. Tel.: +7 (383) 330-22-40. E-mail: yuripopkov54@mail.ru 


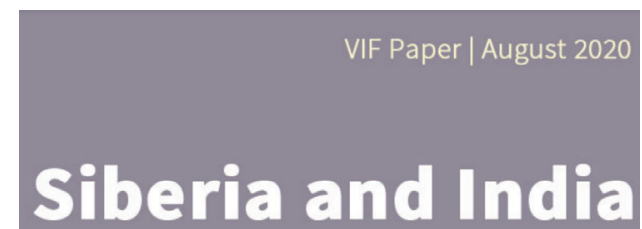

Historical Cultural Affinities

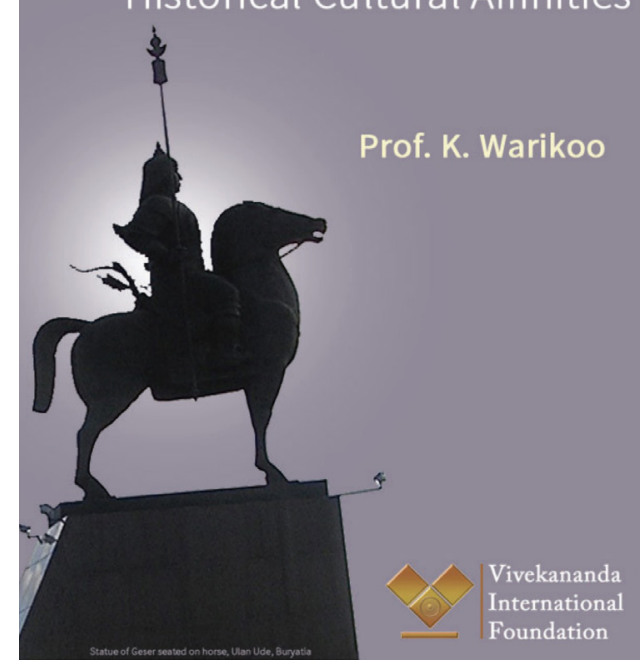

Фото 1. Обложка издания К. Warikoo «Siberia and India: Historical Cultural Affinities». Photo 1. The cover of K. Warikoo's book "Siberia and India: Historical Cultural Affinities".

Целью настоящей статьи является анализ идей и конкретного содержания книги индийского ученого Кулбхушана Варику «Сибирь и Индия: историко-культурное родство» (K. Warikoo «Siberia and India: Historical Cultural Affinities») (Warikoo, 2020). Она была опубликована на английском языке в 2020 г. (фото 1) в Нью-Дели Международным фондом Вивекананды ${ }^{1}$.

Доктор Варику (фото 2) - известный специалист по Центральной Азии, бывший профессор Центра Центрально-азиатских исследований и Школы Международных исследований университета им. Дж. Неру, сейчас работает старшим научным сотрудником Мемориального музея и библиотеки Дж. Неру в г. Нью-Дели. Он знаком сибирским индологам и востоковедам, как редактор международного научного журнала Himalayan and Central Asian Studies ${ }^{2}$, ряд номеров которого был специально посвящен истории и культуре отдельных регионов Сибири. В том числе один из них в 2019 г. включал исследования Тувы (фото 3).

Исследователь неоднократно бывал в Сибири, знакомился с традициями населяющих ее народов, особое внимание уделяя историческим связям между Сибирью и Индией, фактам их культурной и религиозной общности.

Рецензируемая работа обобщает материалы, собранные профессором Варику во время проводившегося им на протяжении нескольких лет полевого исследования в республиках Сибири: в Бурятии (2007), Хакасии (2009), Горном Алтае (2014 и 2015) и Туве (2016). Главной целью этих научных экспедиций являлся поиск конкретных фактов культурного параллелизма между Индией и Сибирью.

Выход в свет данной книги знаменателен, на наш взгляд, по двум причинам. Во-первых, он свидетельствует о важности и перспективности совместной работы индийских и сибирских ученых, ясно осознающих, что уходящие в глубь тысячелетий связи между Северной и Южной Евразией способны не только многое прояснить в этно- и культурогенезе сибирских и индийских народов, но и дать импульс современному сотрудничеству в самых разных областях ${ }^{3}$. Во-вторых, д-р Варику закладывает очень близкие к позициям российских ученых методологические установки исследования, справедливо утверждая вслед за Ю. Н. Рерихом, что именно буддизм стал первоначально той религиознокультурной силой, которая способствовала объединению народов Южной и Северной Евразии, а также созданию основ будущего индийско-сибирского сотрудничества. Кроме этого, он трактует Россию как евразийскую, а не европейскую державу, что соответствует современным научным взглядам на российскую цивилизационную идентичность.

Отметим и еще одно обстоятельство, определяющее интерес к работе индийского ученого и делающее актуальным обсуждение содержания его книги. Сравнительные межстрановые (и межрегиональные) социокультурные исследования, осуществляемые представителями разных государств и научных традиций, являются безусловно важными и востребованными. В то же время они накладываютдополнительные требования к профессионализму и ответственности исследователя в ситуации погружения в «незнакомое поле». Нам самим при- Фото 2. Доктор Варику. ходилось неоднократно сталкиваться с серьезными затруднениями в понимании

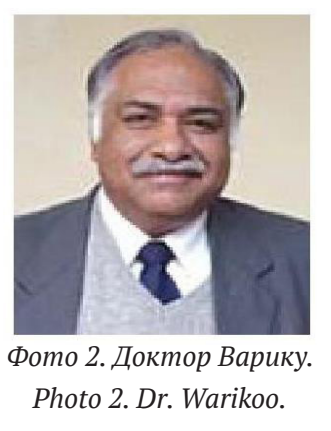

\footnotetext{
${ }^{1}$ Книга есть в открытом доступе: https://www.vifindia.org/sites/default/files/Siberia-and-India-Historical-CulturalAffinities.pdf (дата обращения: 02.03.2021).

${ }^{2}$ Сайт журнала: https://himalayanresearch.org/journal.html

3 Здесь можно указать на вышедшую недавно совместную российско-индийскую монографию: Алтай и Гималаи как уникальные культурно-биосферные регионы Евразии (Алтай и Гималаи ..., 2017), с которой можно познакомиться в электронной библиотеке портала «Тува.Азия»: https://www.tuva.asia/lib/books_regions/9180altay-i-gimalai.html
} 
сути конкретных проблем, а также их специфического контекста, при проведении исследований в Канаде, Монголии, Индии.

Для преодоления возникающих препятствий требуется, в частности, особая предварительная подготовка, в том числе по освоению существующих материалов и публикаций по данной проблеме. К сожалению, такое не всегда происходит в той мере, которая необходима для получения качественного результата. Для примера сошлемся на работу В. Г. Дацышена, непосредственно касающуюся данной темы (Дацышен, 2011). Наш коллега подробно анализирует содержание статьи индийского историка Шарада К. Сони «Сибирская республика Тува» (Сони, 2008), акцентируя внимание на слабых ее сторонах и неточностях, приводящих к искажению исторических фактов и погрешностям в их оценке. На этой основе автор делает справедливый вывод, имеющий отношение не только к данной статье: «Однако, зачастую, иностранные историки игнорируют российские архивы и работы местных ученых. В результате возникает крайне упрощенная и значительно искаженная картина исторического развития российских регионов» (Дацышен, 2011: 200).

Возвращаясь к рецензируемой работе, отметим, что уже на первой ее странице индийский исследователь обращает внимание на важную роль буддизма:

«Индия и Евразия имели тесные социальные и культурные связи, поскольку буддизм распространился из Индии в Центральную Азию, Монголию, Бурятию, Туву и далее. Буддизм обеспечил прямую связь

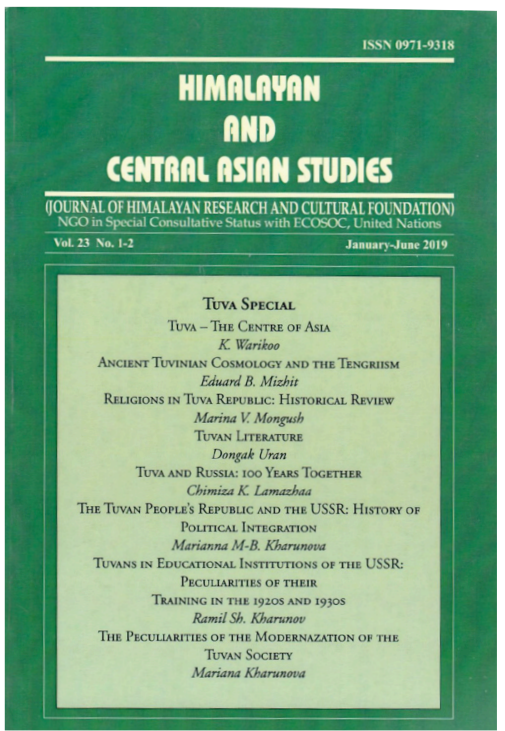

Фото 3. Обложка специального выпуска журнала Himalayan and Central Asian Studies, посвященного Туве.

Photo 3. The cover of a special issue of the journal "Himalayan and Central Asian Studies" dedicated to Tuva. между Индией и народами Сибири..., которые имеют явное историко-культурное родство с народами Индийских Гималаев, в частности, благодаря общим традициям и буддийской культуре. Возрождение буддизма в Сибири имеет огромное значение для Индии с точки зрения восстановления и оживления утраченных связей. Евразийство России, которая в силу своего географического положения является евразийской державой, сближает ее с Индией в историко-культурном, политическом и экономическом планах» (Warikoo, 2020: 4; здесь и далее - перевод С. М. Журавлевой).

Монография д-ра Варику относится к классическому жанру путевых научных очерков, «отражая опыт путешествий автора по Республикам Бурятия, Хакасия, Алтай и Тыва Российской Федерации, выявляя некоторые общности традиций и верований, до сих пор распространенных в этом сибирском регионе и в Индии» (там же). Однако подобный жанр вовсе не исключает тонких наблюдений и важных теоретических обобщений автора, которые, по его собственным словам, призваны инициировать дальнейшие «совместные исследования для углубленного изучения различных аспектов древней истории, культуры, расовых движений и археологических находок в Индии и Евразии, общих источников и корней индийской и сибирской культур и цивилизаций» (там же: 37).

Подобные тонкие наблюдения и замечания автора мы встречаем в разных разделах его книги, посвященных Бурятии и Алтаю, Хакасии и Туве. Так, описывая свое посещение Бурятии, д-р Варику с явной симпатией констатирует факт продуктивного сосуществования здесь шаманизма, буддийской и русской культурных традиций, что позволяет не только сохранять все богатство местного культурного наследия, но и находить глубинное историческое родство различных народов. В этой связи особое внимание индийский исследователь обращает на необходимость дальнейших исследований эпоса о Гэсэр-хане, распространенность которого среди самых разных народов Евразии одним из первых отметил еще Г. Н. Потанин. Легенды о Гэсэре и ее распространение в Центральной Азии, Монголии, на Тибете плодотворно изучал Ю. Н. Рерих, который написал специальные статьи на эту тему (Рерих, 1999: 56-87). «Следует отметить, - пишет в этой связи д-р Варику, - что эпос о героическом царе Гэсэре зафиксирован в поэзии и прозе всей Центральной Азии, в Тибете и в Каракорумских Гималаях. То, что тибетские, монгольские, бурятские, ладакхские сказители, а также сказители народа балти ${ }^{1}$ сохраняют устную традицию исполнения сказаний о Гэсэре, свидетельствует о древнейшем культурном родстве между Индийскими Гималаями и Бурятией» (Warikoo, 2020: 8).

${ }^{1}$ Балти (балчи) - народ, расселенный в Западных Гималаях, в том числе в современном штате Индии ХимачалПрадеш. 
Рассказывая о своем путешествии на Алтай, автор отмечает огромную роль путешествий, художественного и научного творчества Н. К. Рериха, который впервые указал на значение культурной меридиональной евразийской оси Алтай-Гималаи, назвав эти великие горные системы двумя устоями Евразии. К тому же Н. К. Рерих был первым, кто осуществил конкретные компаративистские сибирско-гималайские исследования. Д-р Варику в целом очень высоко оценивает его деятельность, отмечая не только выдающийся вклад в укрепление российско-индийских связей, но и в мировую культуру в целом:

«Николай Рерих расширил понятие культуры, включив в него космическую эволюцию человечества, этику и духовный опыт человека, красоту, знание, науку, искусство, образование, историю и традиции. Он проповедовал мир через культуру, которая объединяет в себе искусство, науку и религию. Будучи творческим художником, он создал Знамя Мира, ставшее символом единства человечества и его культур» (Warikoo, 2020: 32-33).

Вторая крупная фигура, на которую обращает внимание д-р Варику, это индийский исследователь Б. Г. Тилак ${ }^{1}$ с его знаменитой книгой «Арктическая родина в ведах» (Tilak, 1903).

«В этой книге, - замечает автор, - Тилак выдвинул идею о том, что Северный полюс был первоначальным домом ариев в доледниковый период², который они вынуждены были покинуть из-за ледяного покрова и мигрировать в северные части Европы и Азии в поисках новых мест расселения... Никогда не путешествуя так далеко, ... Тилак обладал необыкновенным воображением, видением и знаниями. Его труды и вклад в науку должны быть глубоко изучены профессиональными историками, астрономами и философами и получить широкое распространение» (Warikoo, 2020: 19-20).

Следует, с одной стороны, согласиться с автором в вопросе о недостаточной вовлеченности наследия Б. Тилака в обозначенные отрасли научного знания, с другой стороны - отметить признание важного вклада его идей в формирование философии Севера как составной части мировой философии (Попков, Тюгашев, 2006: 36-40).

Столь высокая оценка исследований Б. Г. Тилака д-ром Варику связана еще и с тем, что представления о мировой горе Меру, которую Б. Г. Тилак помещал на Северном полюсе, оказываются широко распространенными среди народов Северной Евразии, в том числе среди монголов и алтайцев. Так, на Алтае исключительным почитанием окружены г. Белуха (Уч-Сумер) и г. Уч-Энмек, главные вершины Катунского и Теректинского хребтов, которым также приписывается осевое положение в мировом пространстве. Почитание гор, как сакральных центров традиционных культур, где священное Небо соприкасается с землей, трехчастное вертикальное членение мира, складывание священных каменных обо на горных перевалах и их обход посолонь, - все эти элементы традиционных представлений, по мысли д-ра Варику, являются общими и для сибирских, и для гималайских народов.

Факты несомненной культурно-исторической связи между Индией и Сибирью автор обнаруживает и в Хакасии. Он обращает внимание на близость сюжетов сибирских и гималайских петроглифов, где, например, часто встречается общий свастический орнамент; на почитание священных камней, которые могут оказывать на человека лечебное воздействие; на сакральный характер березы, чьи ветви практически одинаково украшаются лентами в Сибири и в Индийских Гималаях. «Береза считается священной в Сибири, так же, как и в Индии», пишет он в этой связи (Warikoo, 2020: 30).

Заметим, что наличие общего свастического орнамента представляет, скорее, типологическую закономерность, отражающую поклонение Солнцу, что находит свои проявления не только в Индии,

\footnotetext{
${ }^{1}$ Бал Гангадхар Тилак (1856-1920) известен в основном как деятель Индийского национального конгресса, его радикального крыла, представители которого в начале XX века выступали за полную независимость Индии от Британии. Он считается также лидером-националистом. Будучи маратхом по национальности, выступал за возрождение этнического самосознания своего народа и индийцев в целом. Был школьным учителем до прихода в политику и поддерживал Арктическую теорию. При этом апелляция к индоариям была связана с Ведами, которые, как и индуизм в целом, он пытался интерпретировать по-своему - с точки зрения необходимости проводить активную политику (https://ru.qaz.wiki/wiki/Bal_Gangadhar_Tilak). Поэтому считать Б. Тилака исследователем следует с определенной долей условности, имея в виду, что он был, прежде всего, политическим деятелем.

${ }^{2}$ Уточним, что данную идею изначально выдвинул американский историк, ректор Бостонского университета У. Уоррен. В 1885 г. он опубликовал книгу с красноречивым названием «Найденный рай: колыбель человечества на Северном полюсе» (переводное издание: Уоррен, 2003; о роли его идей в формировании философии Севера см.: Попков, Тюгашев, 2006: 35-36). Он считал Северный полюс прародиной многих, если не всех древних народов, включая ариев, и цивилизаций, в том числе легендарных - Атлантиды, Гипербореи. Б. Тилак поддержал и развил эту теорию применительно к ариям.
} 
но также в Западной Азии и во Внутренней Евразии. То же самое, как полагает Л. Г. Ерекешева, касается священных камней, характеризующих типологически схожий элемент представлений людей древности вне зависимости от географии. Почитание камней, деревьев и других явлений природы как сакральных предметов в наибольшей степени развито в периоды распространения шаманизма и политеизма (Yerekesheva, 2019). Возможно, д-ру Варику следовало отметить, какие символы культуры являются универсальными, а какие одновременно могли иметь более выраженную межрегиональную специфику и генезис.

Столь же значимые сибирско-индийские культурные параллели д-р Варику находит и в Туве. Он посетил ее в 2016 г. В начале очерка автор указывает, что Республика Тыва занимает срединное положение в Евразии, граничит с Монголией, Алтаем, Хакасией, Красноярским краем. Культура тувинцев демонстрирует органическое взаимодействие буддизма и шаманизма, где центральной объединяющей идеей является жизнь в гармонии с природой.

«Тувинцы, - пишет он, - часто обращаются к шаманам для исцеления своих недугов и для решения других своих проблем. Шаманы посещают буддийские монастыри, чтобы вознести молитвы. Обе религии сосуществуют здесь, следуя базовым принципам взаимного уважения и гармонии с природой» (Warikoo, 2020: 33).

Автор обращает внимание на то, что в начале 1990-х гг. в Туве появляются шаманские организации, что в 1993 г. здесь был проведен 1-й международный научно-практический семинар ученыхшамановедов и шаманов (более подробно о шаманском движении в этот период см.: Харитонова, 2006: 165-167). По мнению исследователя, возрождение шаманизма и поддержка данного процесса со стороны властей республики отражает растущий интерес российского и международного сообщества к этой важной составляющей культуры коренных народов Сибири.

Исследователь делает далее справедливый вывод:

«Шаманские гимны и алгышы (благопожелания) сегодня переведены на немецкий и английский языки. Шаманы также выполняют свои ритуальные церемонии. Культы оваа (духов-хранителей места) и ээрэн (покровителей семьи), которые являются шаманскими традициями, были приняты и тувинскими буддистами» (Warikoo, 2020: 36; курсивы источника. - Авт.).

С большой симпатией д-р Варику пишет о тувинском буддизме, подчеркивая:

«После распада бывшего СССР в Туве произошло беспрецедентное возрождение коренного языка, культуры, верований и буддизма. Здесь построено около 20 буддийских молитвенных домов (дуган) и 15 буддийских монастырей (хурее). Визит Далай-ламы в Туву в 1992 году дал большой толчок возрождению буддийских практик, изданию буддийских текстов, строительству монастырей и так далее» (там же: 34).

Он отмечает широкое распространение буддизма среди современных тувинцев и поддержку, которую они получают со стороны государства:

«Строительство нового центрального буддийского монастыря в Кызыле началось в 2014 году на месте, указанном Далай-ламой. Д-р Каадыр-оол Бичелдей, бывший министр образования и науки Тувы, и сам буддист, возглавляет движение за восстановление исторического, культурного языкового и буддийского наследия республики. Многие тувинцы-буддисты делают пожертвования на эти проекты, которые также получают поддержку от правительства Тувы. Федеральное правительство России терпимо относится к этому процессу, и многие тувинцы сегодня чувствуют себя свободными, поскольку могут исповедовать свою религию и культуру. Фестиваль музыки и культуры “Устуу-Хурээ” начал проводиться в 1999 году, когда была осуществлена реконструкция руин древнего буддийского храма в Чадане» (там же: 35 ).

К сказанному автором можно было бы добавить, что сегодня развивается и буддийское паломническое движение. В 2020 г. в г. Кызыле было проведено специальное исследование Ч. К. Ламажаа и ее коллег на эту тему с интервьюированием группы тувинцев, которые сопровождают религиозных паломников или сами участвуют в заграничных паломнических турах. По итогам интервью авторы делают вывод о наличии важной тенденции: тувинцами по мере взросления осознается необходимость перехода от буддизма по традиции - к буддизму по вере, то есть усвоения основ данного религиозного учения, хотя этот процесс является достаточно противоречивым (Ламажаа, Бичелдей, Монгуш, 2020).

Надо сказать, что проблема распространения и бытования буддизма в Туве в разные исторические периоды - достаточно хорошо разработанная тема. Среди наиболее обстоятельных исследований по этой проблеме можно выделить работы М. В. Монгуш (Монгуш, 1992, 2001) и О. М. Хомушку (Хомушку, 1998, 2005). В последнее время она подкрепляется результатами специальных социологических исследований среди молодежи (Бадмаев и др., 2020). 
Индийский ученый отмечает, что большую роль в сохранении традиций тувинского народа играет его язык. Как он пишет, сегодня русский и тувинский языки имеют одинаково высокий статус:

«Тувинский язык относится к алтайской семье тюркской языковой группы. Это также “хороший сосед” монгольского языка. Раньше тувинский язык основывался на древнем монгольском письме. Позже был переведен на латиницу. После присоединения к Советскому Союзу была принята кириллица. Некоторые местные эксперты считают, что Кириллица не подходит тувинскому языку, ибо не отражает всех его звуков. Тувинцы считают, что шаги по сохранению и популяризации тувинского языка и культурного наследия не следует рассматривать как какую-либо сепаратистскую тенденцию» (Warikoo, 2020: 36-37).

Д-р Варику на страницах своей книги несколько раз высказывает важную мысль, что внимание народа к своему языку и культуре должно органически дополняться взаимодействием с другими культурно-языковыми и религиозными традициями. Это служит развитию и мировой, и национальной культур.

В то же время исследователь, говоря о языке, не фиксирует, в силу краткости своего пребывания в Туве, комплекс серьезных проблем, связанных с неоднозначной текущей языковой ситуацией в республике, определяемой в том числе современными тенденциями государственной политики в данной области. Не останавливаясь здесь детально на этой теме, сошлемся на только что вышедшую специальную статью, где она рассматривается подробно с акцентом на проблемах развития билингвизма в республике в настоящее время (Арефьев, Бахтикиреева, Синячкин, 2021). В частности, филологами акцентируется дифференциация сфер использования тувинского и русского языков, отмечается потеря конкурентноспособности тувинского языка в ситуации, когда он лишился статуса языка обучения. «Такая неравновесная билингвальная ситуация, - отмечают авторы, - в перспективе может привести к потерям в процессе межпоколенной передачи тувинской культуры (там же: 255).

Как и в других регионах Сибири, где живут ее коренные народы, автор находит в Туве примеры почитания священных вершин. Вот что он пишет о горе Хайыракан, расположенной в ста пяти километрах от г. Кызыла: «Тувинцы считают эту гору священной, и существует много мистических легенд, связанных с Хайыраканом. Тувинцы приходят сюда, чтобы вознести молитвы Будде, и забирают с собой горсть священной земли» (Warikoo, 2020: 35). Заканчивая описание своего посещения Тувы, индийский ученый делает общий вывод: «Тува переживает период возрождения своего традиционного языка, культуры, традиций, буддийских и шаманистских верований» (там же: 37).

Очень важны, на наш взгляд, констатации тех культурных и религиозных параллелей, на которых останавливается д-р Варику в завершающем разделе своей небольшой по объему, но очень интересной и знаковой книги:

«Концепции трех миров, третьего глаза и трезубца, которые были воплощены на древних камнях возрастом более 2000 лет и которые почитались и продолжают почитаться как в Хакасии, так и на Алтае, имеют прямое сходство с традицией и космической философией, распространенными в Индии и сегодня. Точно так же практика почитания озер, водных источников, гор, священного дерева березы в Евразии очень похожа на индийскую традицию и практику. Алтайцы, тувинцы и другие коренные народы совершают огненные обряды, а также стрижку маленьких детей (мундан) так же, как это делают индусы в Индии. Алтайцы также верят в Семь Звезд (Семь Риши в Индии) ${ }^{1}$ и в Семь Каанов на Алтае. В Бурятии, Туве и на Алтае существует также традиция класть амулеты во время закладки первого камня в фундамент дома. Эта практика аналогична той, что существует в Индии. Таким образом, становится очевидной необходимость дальнейшего выявления общих традиций, верований и обычаев у народов Сибири и Индии» (там же: 37-38).

Очень символична и значима фраза, которой д-р Варику завершает свой труд. Высказанная носителем великой культурной традиции, славящейся своим умением налаживать диалог между разными народами и культурами, она должна способствовать росту самосознания Сибири, занимающей срединное положение на пространствах Евразии, находящейся в средоточии ее широтных и меридиональных транспортных, торговых, культурных и паломнических путей. «Сибирь - это тот коридор, благодаря которому можно возродить культурное и цивилизационное взаимодействие народов» (там же: 38).

Д-р Варику, будучи индийцем и родом из Кашмира, стремился показать значимость культуры древних индоариев и ее влияние на другие культуры, находя и сопоставляя традиции народов Сибири и Индии. В этом состоит, по нашему убеждению, его большая заслуга, поскольку исследование

${ }^{1}$ Речь идет о созвездии Большой медведицы, наблюдения которой присутствуют у многих народов мира, но называется она везде по-разному. 
евразийского социокультурного пространства по линии «Восток - Запад» является достаточно разработанной темой, в то время как его меридиональное измерение по линии «Север - Юг» до сих пор является редким предметом для изучения.

Специалистам хорошо известно, что многие явления имеют универсальный, или же типологически закономерный характер, то есть обладают схожестью не только в меридиональном, но и в широтном, горизонтальном измерении. С этой точки зрения существует возможность постановки обсуждаемых вопросов в более широком контексте с выделением универсальных характеристик культуры и последующим детализированным их изучением в разных ареалах, в том числе в контексте рассмотрения схожести и взаимодействия народов Севера и Юга. Такой подход и соответствующая проблематизация могут стать основой для международных междисциплинарных проектов в будущем.

Перспективным представляется расширение сотрудничества в области сравнительно-культурологических исследований с включением в предметное поле всех горных территорий Азии и связанных с ними культур т. н. Высокой Азии (Алтай, Гималаи, Тянь-Шань, Куньлунь, Памир, Гиндукуш). Плодотворным видится также изучение в компаративистском ключе религиозных верований народов в ретроспективе и перспективе современности, причем, не ограниченное только буддизмом и шаманизмом. Д-р Варику четко зафиксировал связь между ними применительно к Туве. В Индии эта связь также хорошо проявляется на севере - в Химачал-Прадеше и в Ладакхе. Однако важную роль в культуре народов Сибири, Центральной Азии и Индии сыграли также ислам и христианство (особенно старообрядчество), а также несторианство и манихейство. В той или иной форме они активно взаимодействовали с буддийскими и шаманистскими верованиями и практиками, создав сложные и разнообразные линии религиозного диалога в так называемой Большой Евразии, в том числе и по линии «Север - Юг». Они заслуживают отдельного изучения, а идеи, высказанные в книге д-ра Варику, могут быть значительным методологическим и концептуальным подспорьем в подобных сравнительно-религиоведческих и сравнительно-культурологических евразийских исследованиях.

В последнее время предприняты инициативы по расширению научного сотрудничества между сибирскими и индийскими учеными, в том числе в рамках международной исследовательской группы «Алтайско-Гималайская Инициатива» ${ }^{1}$ Участниками данной группы организованы серьезные мероприятия, проведены исследования, осуществлены интересные публикации (Алтай-Гималаи ... , 2015; Алтай и Гималаи ..., 2017).

Подводя итоги, можно сказать, что работа д-ра Варику вносит свой посильный вклад в благородное дело взаимного познания культур народов Сибири и Индии. Хочется надеяться, что этот исследовательский процесс будет продолжен в целях укрепления меридионального взаимодействия и сотрудничества, как существенно значимой характеристики общего евразийского социокультурного пространства.

\section{Благодарности}

Авторы рецензии благодарят д-ра Варику за согласие опубликовать его фото из книги; за ценные замечания и идеи, высказанные д. и. н., проф. Л. Г. Ерекешевой (Казахстан).

\section{СПИСОК ЛИТЕРАТУРЫ}

Алтай - Гималаи: традиционные знания и инновации в развитии горных и предгорных регионов Евразии (2015): материалы 1-го российско-индийско-монгольского семинара, 19-20 июня 2015 г. / под ред. Н. А. Колпакова, И. В. Фотиевой. Барнаул : Изд-во Фонда «Алтай-21 век». 228 с.

Алтай и Гималаи как уникальные культурно-биосферные регионы Евразии (2017) / под ред. А. В. Иванова, И. В. Фотиевой. Барнаул : РИО Алтайского ГАУ. 336 с.

\footnotetext{
${ }^{1}$ См. об этом: Иванов А. В., Попков Ю.В. Алтай-Гималаи: совместные сибирско-индийские исследования горных регионов Евразии [Электронный ресурс] // Тува.Азия. 2016, 19 ноября. URL: https://www.tuva.asia/ news/asia/8844-gimalai.html (дата обращения: 28.02.2021); Фотовыставка Юрия Попкова «Неотрадиционализм у народов Гималаев» [Электронный ресурс] // Тува.Азия. 2018, 23 марта. URL: https:/www.tuva.asia/news/ asia/9206-fotovystavka.html (дата обращения: 28.02.2021).
} 
Арефьев, А. Л., Бахтикиреева, У. М., Синячкин, В. П. (2021) Проблемы билингвизма в системе школьного языкового образования Республики Тыва // Новые исследования Тувы. № 1. C. 255-272. DOI: https://doi.org/10.25178/ nit.2021.1.14

Бадмаев, В. Н., Уланов, М. С., Ламажаа, Ч. К., Бичелдей, У. П., Антонов, В. И., Очирова, О. А. (2020) Россия и буддийский мир глазами молодежи Тувы, Бурятии и Калмыкии (по материалам социологического опроса) // Новые исследования Тувы. № 1. С. 35-49. DOI: https://doi.org/10.25178/nit.2020.1.3

Дацышен, В. Г. (2011) Российские регионы в работах зарубежных исследователей: «Сибирская республика Тува» индийского историка Ш. К. Сони // Ойкумена. Регионоведческие исследования. № 2. С. 200-206.

Ламажаа, Ч. К., Бичелдей, У. П., Монгуш, А. В. (2020) Тувинское буддийское паломничество: от традиции к веpe // Новые исследования Тувы. № 4. C. 135-155. DOI: https://doi.org/10.25178/nit.2020.4.10

Монгуш, М. В. (1992) Ламаизм в Туве : историко-этнографическое исследование. Кызыл : Тувинское книжное издательство. 144 с.

Монгуш, М. В. (2001) История буддизма в Туве (вторая половина VI - конец XX в.). Новосибирск : Наука. 200 с.

Попков, Ю. В., Тюгашев, Е. А. (2006) Философия Севера: Коренные малочисленные народы Севера в сценариях мироустройства. Салехард ; Новосибирск : Сибирское научное издательство. 376 с.

Рерих, Ю. Н. (1999) Тибет и Центральная Азия: Статьи, лекции, переводы. Самара : Издательский дом «Агни». 368 c.

Уоррен, У. Ф. (2003) Найденный рай на Северном полюсе : пер. с англ. Н. Гусевой. М. : ФАИР-ПРЕСС. 480 с.

Харитонова, В.Н.(2006) Феникс из пепла? Сибирский шаманизм на рубеже тысячелетий. М. : ИЭА РАН. 372 с.

Хомушку, О. М. (1998) Религия в истории культуры тувинцев. М. : Институт этнологии и антропологии РАН. $177 \mathrm{c}$.

Хомушку, О. М. (2005) Религия в культуре народов Саяно-Алтая. М. : РАГС. 225 с.

Сони, Ш. К. (2008) Сибирская республика Тыва // Россия в Азии: перспективы партнерства и взаимодействия : сб. мат. междунар. науч. конф. Новосибирск : ИД «Сова». С. 269-276.

Yerekesheva, L. (2019) Syncretism of Religious Beliefs in Western Himalayas’s Lahoul // Südasien-Chronik/South Asia Chronicle. № 9. P. 83-117. DOI: https://doi.org/10.18452/20994

Tilak, Bal Gangadhar (1903) The Arctic Home in the Vedas. Poona : Tilak Bros. 470 p.

Warikoo, K. (2020) Siberia and India: Historical Cultural Affinities. New Delhi : Vivekananda International Foundation. $54 \mathrm{p}$.

Дата поступления: 12.02.2021 2.

\section{REFERENCES}

Altai - Gimalai: traditsionnye znaniia i innovatsii v razvitii gornykh i predgornykh regionov Evrazii [Altai - Himalayas: traditional knowledge and innovations in the development of mountain and foothill regions of Eurasia] (2015) : Proceedings of the 1st Russian-Indian-Mongolian seminar, June 19-20, 2015 / ed. by N. A. Kolpakov and I. V. Fotieva. Barnaul, Publishing House of the Altai - 21st Century Foundation. 228 p. (In Russ.).

Altai i Gimalai kak unikal'nye kul'turno-biosfernye regiony Evrazii [Altai and the Himalayas as unique cultural and biosphere regions of Eurasia] (2017) / ed. by A. V. Ivanov and I. V. Fotieva. Barnaul, Editorial and Publishing Unit at Altai State Agrarian University. 336 p. (In Russ.).

Arefiev, A. L., Bakhtikireeva, U. M. and Sinyachkin, V. P. (2021) Problemy bilingvizma v sisteme shkol'nogo iazykovogo obrazovaniia Respubliki Tyva [Bilingualism in language education in secondary schools of the Republic of Tuva]. New Research of Tuva, no. 1, pp. 255-272. (In Russ.). DOI: https://doi.org/10.25178/nit.2021.1.14

Badmaev, V. N., Ulanov, M. S., Lamazhaa, Ch. K., Bicheldey, U. P., Antonov, V. I. and Ochirova, O. A. (2020) Rossiia i buddiiskii mir glazami molodezhi Tuvy, Buriatii i Kalmykii (po materialam sotsiologicheskogo oprosa) [Russia and the Buddhist world through the eyes of the youth in Tuva, Buryatia and Kalmykia: a sociological survey and its outcomes]. New Research of Tuva, no. 1, pp. 35-49. (In Russ.). DOI: https://doi.org/10.25178/nit.2020.1.3

Datsyshen, V. G. (2011) Rossiiskie regiony v rabotakh zarubezhnykh issledovatelei: «Sibirskaia respublika Tuva» indiiskogo istorika Sh. K. Soni [The Russian regions in works of foreign researchers: "Siberian republic Tuva" of Indian historian S. K. Soni]. Ojkumena. Regional researches, no. 2, pp. 200-206. (In Russ.).

Lamazhaa, Ch. K., Bicheldey, U. P. and Mongush, A. V. (2020) Tuvinskoe buddiiskoe palomnichestvo: ot traditsii k vere [Tuvan Buddhist pilgrimage: from tradition to the faith]. New Research of Tuva, no. 4, pp. 135-155. (In Russ.). DOI: https:// doi.org/10.25178/nit.2020.4.10 
Mongush, M. V. (1992) Lamaizm v Tuve : istoriko-etnograficheskoe issledovanie [Lamaism in Tuva: a historical and ethnographic study]. Kyzyl, Tuvan Book Publisher. 144 p. (In Russ.).

Mongush, M. V. (2001) Istoriia buddizma v Tuve (vtoraia polovina VI - konets XX v.) [The History of Buddhism in Tuva (latter half of the 6th - late 20th cc.)]. Novosibirsk, Nauka. 200 p. (In Russ.).

Popkov, Yu. V. and Tiugashev, E. A. (2006) Filosofiia Severa: Korennye malochislennye narody Severa $v$ stsenariiakh miroustroistva [Philosophy of the North: Indigenous small-numbered peoples of the North in the scenarios of the world order]. Salekhard; Novosibirsk, Siberian Scientific Publishing House. 376 p. (In Russ.).

Roerich, Yu. N. (1999) Tibet i Tsentral'naia Aziia: Stat'i, lektsii, perevody [Tibet and Central Asia: Articles, lectures, translations]. Samara, Publishing House “Agni”. 368 p. (In Russ.).

Warren, W. F. (2003) Naidennyi rai na Severnom poliuse [Paradise found, the cradle of the human race at the North Pole: $A$ study of the primitive world] : transl. from Engl. by N. Guseva. Moscow, FAIR-PRESS. 480 p. (In Russ.).

Kharitonova, V. I. (2006) Feniks iz pepla? Sibirskii shamanizm na rubezhe tysiacheletii [A Phoenix from the ashes? Siberian shamanism at the turn of the millennium]. Moscow, Nauka. 372 p. (In Russ.).

Khomushku, O. M. (1998) Religiia $v$ istorii kul'tury tuvintsev [Religion in the history of Tuvan culture]. Moscow, Institute of Ethnology and Anthropology RAS. 177 p. (In Russ.).

Khomushku, O. M. (2005) Religiia v kul'ture narodov Saiano-Altaia [Religion in the culture of the Sayano-Altai peoples]. Moscow, RAGS. 225 p. (In Russ.).

Soni, Sh. K. (2008) Sibirskaia respublika Tyva [Siberian Republic of Tuva]. In: Rossiia v Azii: perspektivy partnerstva $i$ vzaimodeistviia [Russia in Asia: prospects for partnership and interaction]: A collection of materials of the International scientific conference. Novosibirsk, Sova Publishing House. Pp. 269-276. (In Russ.).

Yerekesheva, L. (2019) Syncretism of Religious Beliefs in Western Himalayas's Lahoul. Südasien-Chronik/South Asia Chronicle, no. 9, pp. 83-117. DOI: https://doi.org/10.18452/20994

Tilak, Bal Gangadhar (1903) The Arctic Home in the Vedas. Poona, Tilak Bros. 470 p.

Warikoo, K. (2020) Siberia and India: Historical Cultural Affinities. New Delhi, Vivekananda International Foundation. 54 p.

Submission date: 12.02.2021. 